\title{
INOVASI PENGERING IKAN MENGGUNAKAN HOME DRIED SYSTEM UNTUK MENINGKATKAN PRODUKSI IKAN PAKANG DESA KUALA GEULUMPANG KECAMATAN JULOK KABUPATEN ACEH TIMUR
}

\author{
Puji Wahyuningsih"1, Wan Alamsyah², Rachmad Almi Putra ${ }^{3}$, T.Andi Fadlly ${ }^{3}$ \\ 1Program Studi Kimia, Fakultas Teknik, Universitas Samudra, \\ 2Program Studi Teknik Sipil, Fakultas Teknik, Universitas Samudra, \\ 3Program Studi Fisika, Fakultas Teknik, Universitas Samudra, \\ rachmad.almi@unsam.ac.id
}

\begin{abstract}
Kuala Geulumpang village is one of the towns in the Julok subdistrict. Most of the community is a business group that processes fish into crackers or known as pakang fish. One of the business group's problems is the drying process, especially in the rainy season, which results from a decrease in the color quality and taste of pakang fish products. This service program aims to provide a solution for drying media that is not dependent on weather conditions, namely a home dried system using an integrated solar panel media based on solar energy through the solar cell and current batteries storage. This method has advantages compared with conventional methods that are not affected by the weather, faster the drying process, and minimizes fish damage caused by decaying so that the quality of the product is maintained and accepted by consumers on time. The application of fish dryer technology is expected to increase the production and quality of pakang fish produced by the community of Kuala Geulumpang Village to improve the community's economy.
\end{abstract}

Keywords: home-dried system, solar panel, pakang fish, Kuala Geulumpang

\begin{abstract}
Abstrak
Desa Kuala Geulumpang merupakan salah satu desa di Kecamatan Julok yang sebagian besar masyarakatnya merupakan kelompok usaha yang mengolah ikan menjadi ikan kerupuk atau dikenal dengan ikan pakang. Salah satu permasalahan yang dialami oleh kelompok usaha tersebut adalah proses pengeringan khususnya pada musim penghujan yang mengakibatnya menurunnya kualitas warna dan rasa dari produk ikan pakang. Program pengabdian ini bertujuan untuk memberikan solusi media pengeringan yang tidak terkendala oleh kondisi cuaca yaitu home dried system menggunakan media panel surya terintegrasi berbasis energi matahari melalui penyimpanan dalam solar cell dan baterai penyimpan arus. Metode ini memiliki keunggulan daripada metode konvensional yaitu tidak dipengaruhi oleh cuaca, proses pengeringan lebih cepat, meminimalisir kerusakan ikan yang diakibatkan pembusukan sehingga kualitas produk tetap terjaga dan dapat diterima oleh konsumen tepat pada waktunya. Melalui penerapan teknologi alat pengering ikan ini diharapkan meningkatkan produksi dan kualitas ikan asin kerupuk yang dihasilkan oleh masyarakat Desa Kuala Geulumpang sehingga mampu meningkatkan perekonomian masyarakat.
\end{abstract}

Kata kunci: home dried system, panel surya, ikan pakang, kuala geulumpang

MARTABE : Jurnal Pengabdian Masyarakat| 20 


\section{PENDAHULUAN}

Desa Kuala Geulumpang merupakan sebuah desa yang terletak di kecamatan Julok Kabupaten Aceh Timur Provinsi Aceh. Sebagian besar masyarakat di desa merupakan kelompok-kelompok usaha yang mengolah ikan menjadi ikan kerupuk atau yang dikenal dengan ikan pakang yang merupakan komoditi unggulan dari desa tersebut. Potensi ini didukung oleh keadaan geografis desa tersebut yang berdekatan dengan laut sehingga produksi ikan sangat melimpah. Salah satu kelompok usaha yang mengolah ikan pakang adalah BUMG Ratana. Pengeringan yang digunakan oleh kelompok usaha BUMG Ratana masih menggunakan pengeringan manual dengan memanfaatkan cahaya matahari langsung sehingga pada musim penghujan proses pengeringan menjadi terhambat. Hal ini mengakibatkan menurunnya kualitas dari ikan pakang yang dihasilkan baik warna maupun rasa serta tingkat kehigienisan produk. Untuk mengatasi kendala masyarakat tersebut perlu dilakukan sebuah inovasi dalam proses pengeringan dari pengeringan tradisional menjadi pengeringan yang lebih modern.

Salah satu inovasi dalam proses pengeringan ikan pakang adalah menggunakan alat Home Dried System menggunakan media panel surya terintegrasi berbasis energi matahari baik secara langsung maupun secara tidak langsung dengan penyimpanan melalui solar cell dan baterai penyimpan arus (Hanafri dkk., 2016). Metode ini memiliki keunggulan daripada metode konvensional yaitu tidak dipengaruhi oleh cuaca, proses pengeringan lebih cepat, meminimalisir kemungkinan pembusukan karena musim penghujan sehingga kualitas produk tetap terjaga dan dapat diterima oleh konsumen tepat pada waktunya (Daryanto dan Suprapto, 2014).

\section{Program}

Pengabdian

Masyarakat ini dilaksanakan dengan melibatkan beberapa pihak sebagai mitra kegiatan, yaitu kelompok usaha pengolahan ikan asin kerupuk yaitu BUMG Ratana dan pemilik toko untuk memasarkan produk yang dihasilkan oleh masyarakat Desa Kuala Geulumpang melalui izin Kepala Desa (Geuchik). Melalui penerapan teknologi alat pengering ikan ini diharapkan meningkatkan produksi dan kualitas ikan pakang yang dihasilkan

\section{METODE}

Kegiatan pengabdian masyarakat dilakukan di Desa Kuala Geulumpang Kecamatan Julok Kabupaten Aceh Tmur selama 5 bulan yaitu awal bulan Juni sampai bulan Oktober 2020. Adapun tahapan-tahapan dalam kegiatan pengabdian masyarakat adalah sebagai berikut:

\section{a. Koordinasi kegiatan}

Pada awal kegiatan, Tim pengabdi melakukan koordinasi kegiatan dengan aparat desa dan masyarakat di Desa Kuala Geulumpang dalam rangka menganalisis permasalahan yang dihadapi oleh masyarakat, khususnya kelompok usaha pengolahan ikan pakang sehingga memberikan solusi untuk menjawab permasalahan yang dihadapi oleh masyarakat Desa Kuala Geulumpang.

\section{b. Sosialiasi kegiatan}

Sosialisasi kegiatan dilakukan
dalam bentuk ceramah dengan
memaparkan materi pelatihan secara
tatap muka dengan tujuan untuk
memberikan informasi yang lebih jelas
kepada masyarakat Desa Kuala
Geulumpang tentang maksud dan tujuan
tim pengabdi mengadakan pelatihan
rancang bangun Home Dried System


kepada masyarakat Desa Kuala Geulumpang.

\section{c. Pelatihan}

Kegiatan pelatihan diadakan dengan mempratikkan secara langsung tentang perakitan alat "Home Dried System”. oleh tim pengabdi bersama masyarakat desa dalam proses pengeringan ikan untuk menghasilkan produk ikan pakang. Selanjutnya, tim pengabdi menjelaskan cara kerja Home Dried System dan bagaimana cara perawatan alat agar dapat digunakan secara berkelanjutan oleh masyarakat.

\section{d. Monitoring dan Pendampingan}

Kegiatan pendampingan dilakukan oleh tim pengabdi dengan mengunjungi lokasi pelatihan di Desa Kuala Geulumpang selama sebulan sekali. Hal ini bertujuan untuk memonitoring dan mengevaluasi perkembangan hasil kegiatan. Pada saat kunjungan, tim pengabdi berdiskusi dengan masyarakat atau mitra mengenai perkembangan kegiatan, pengolahan dan permasalahan yang dihadapi pada saat melakukan pengeringan ikan menggunakan Home Dried System

\section{HASIL DAN PEMBAHASAN}

Pada saat kegiatan pengabdian masyarakat tim melakukan koordinasi terlebih dahulu dengan masyarakat, khususnya kelompok BUMG Ratana yang merupakan mitra kegiatan terkait survey lahan yang akan digunakan untuk membangun Home Dried System. Tahapan kegiatan selanjutnya yang dilakukan oleh tim pengabdi bersama masyarakat adalah sebagai berikut:

\section{a. Pembangunan Home Dried System}

Home Dried System dibangun di Desa Kuala Geulumpang Kecamatan Julok Kabupaten Aceh Timur. Home Dried System memilikii luas bangun $3 \mathrm{x}$ 3 meter persegi. Home Dried System merupakan rumah pengering menggunakan dinding berbahan dasar akrilik dan seng sebagai konduktor panas untuk mempercepat proses pengeringan serta dilengkapi dengan rak-rak pengering sebanyak 10 buah seperti terlihat pada Gambar 1.

b. Perakitan sistem Home Dried System

Sistem Home Dried System terdiri dari panell surya, baterai penyimpan arus, blower, lampu kap halogen 500 Watt sebagai lampu pemanas. Proses pengeringan menggunakan panel surya yang akan menyimpan panas dan lampu pemanas dengan daya tinggi serta blower untuk agar panas didalam Home Dried System tersebar merata sehingga proses pengeringan ikana berlangsung lebih cepat. Sistem Home Dried System ditunjukkan pada Gambar 2.

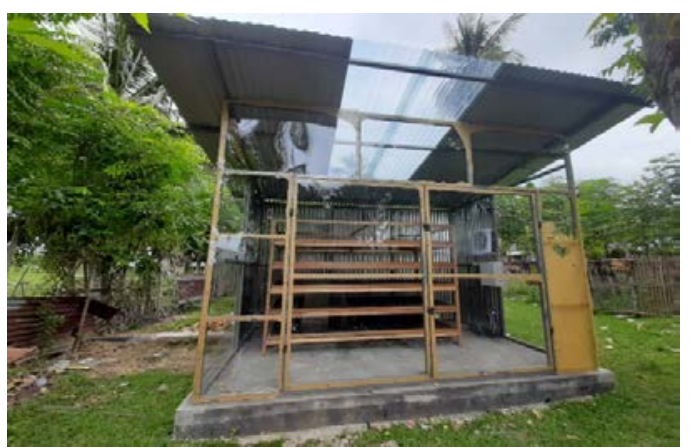

Gambar 1. Rumah Pengering (Home Dried System)

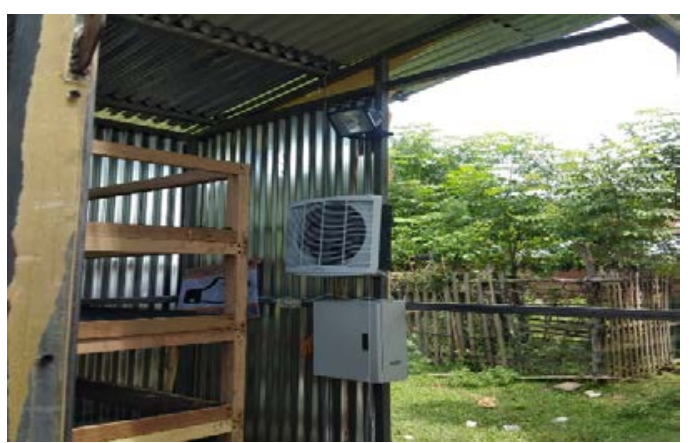

Gambar 3. Perakitan Home Dried System

\section{c. Pelatihan Rancang Bangun Home Dried System}

Kegiatan ini dilakukan pada Tanggal 25 Juli 2020 di BUMG Ratana 
Desa Kuala Gelumpang. Kegiatan ini dihadiri oleh masyarakat, khususnya kelompok usaha yang mengolah ikan menjadi ikan pakang sebanyak 10 orang, perangkat desa yaitu kepala desa, ketua umum urusan desa, dan ketua pemuda serta dosen dan mahasiswa Universitas Samudra yang terlibat langsung dalam kegiatan pengabdian masyarakat (Gambar 3) Kegiatan ini berupa pelatihan dengan memberikan informasi mengenai pemanfaatan Home Dried System sebagai inovasi media pengeringan ikan khususnya pada musim penghujan, cara kerja sistem Home Dried System sebagai pengering, dan cara perawatan alat Home Dried System agar dapat digunakan berkelanjutan oleh masyarakat.

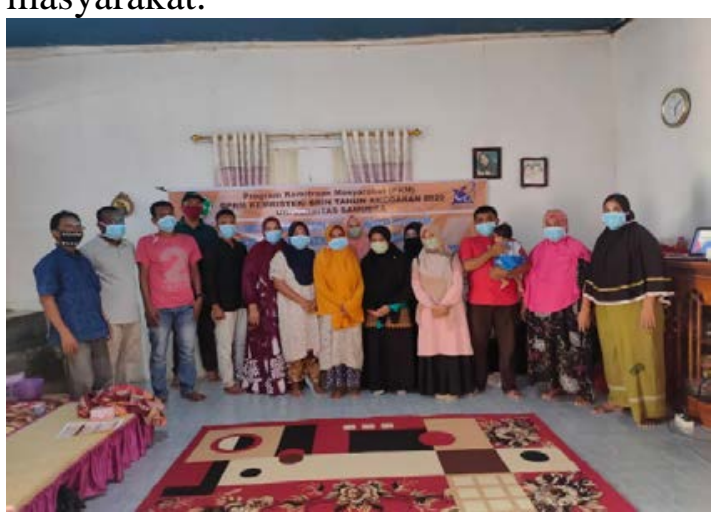

Gambar 4. Kegiatan Pelatihan Rancang Bangun Home Dried System

\section{d. Pengemasan Produk}

Pada kegiatan pengbadian ini masyarakat juga diberi pelatihan mengenai cara pengemasan produk yang menarik agar mampu meningkatkan nilai jual produk ikan pakang sebagai upaya peningkatan perekonomian masyarakat dan memperluas daerah pemasaran produk tersebut. Produk ikan pakang dipasarkan dibeberapa toko kelontong yang ada di wilayah Kota Langsa, Aceh Timur dan Aceh Tamiang. Kemasan produk ikan pakang dapat dilihat pada Gambar 5.

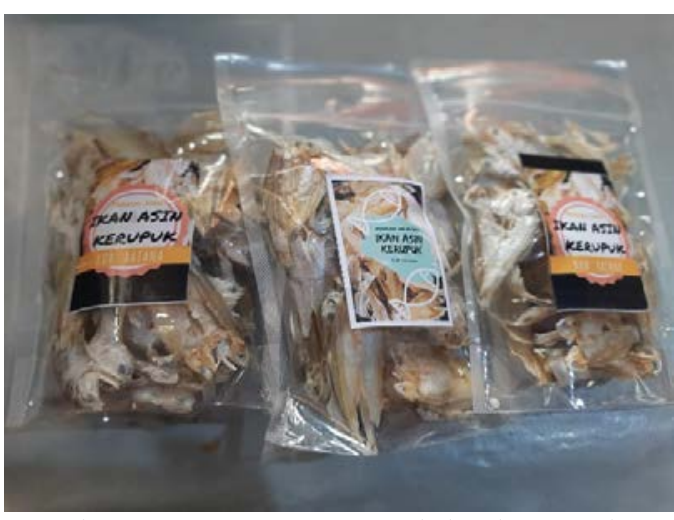

Gambar 5. Kemasan Produk Ikan Pakang Siap Dipasarkan

\section{e. Pendampingan}

Kegiatan

pendampingan merupakan kegiatan yang bertujuan untuk memonitoring dan mengevaluasi perkembangan hasil kegiatan. Dengan adanya kegiatan pendampingan ini diharapkan kegiatan ini dapat dilakukan oleh masyarakat secara berkelanjutan. Pada kegiatan ini, tim pengabdi melakukan pendampingan secara berkala yaitu sebulan sekali untuk mengetahui kemajuan kegiatan, mengindentifikasi permasalahan yang dihadapi pada saat melakukan pengeringan ikan menggunakan Home Dried System.

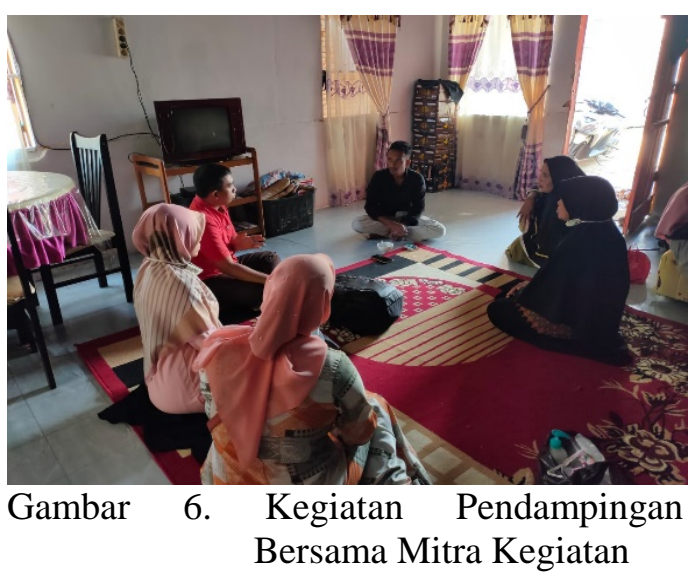

\section{SIMPULAN}

Kegiatan pengabdian ini berupa sosialisasi dan pelatihan rancang bangun Home Dried System untuk 
Puji Wahyuningsih,dkk. Inovasi Pengering Ikan Menggunakan Home Dried System ...

membantu proses pengeringan ikan bagi kelompok usaha pengolahan ikan pakang. Pada kegiatan ini masyarakat dapat memiliki pengetahuan dan keterampilan masyarakat tentang cara kerja sistem Home Dried System dan perawatan alat agar dapat digunakan secara berkelanjutan. Melalui kegiatan ini diharapkan masyarakat dapat menggunakan sistem Home Dried System sebagai solusi permasalahan proses pengeringan ikan khususnya pada musim penghujan yang dapat meningkatkan kualitas produk ikan pakang baik warna maupun rasa agar dapat bersaing dengan produk sejenis lainnya untuk meningkatkan perekonomian masyarakat.

\section{UCAPAN TERIMA KASIH}

Ucapan terima kasih kepada Kemenristek/BRIN melalui Hibah Pengabdian Kepada Masyarakat Tahun Anggaran 2020, Universitas Samudra dan Masyarakat Desa Kuala Geulumpang beserta perangkat Desa atas tercapainya kegiatan pengabdian masyarakat ini.

\section{DAFTAR PUSTAKA}

Daryanto, E., Suprapto. 2014. Kajian Eksperimental Alat Pengering Tenaga Surya Dengan Variasi Sudut Konsentrator Cermin Datar dan Sudut Riblets Untuk Pelat Absorber. Jurnal Saintika. 15(2): 90-105.

Hanafri, H.E., Kustianti, E \& Rahayu, E.L. 2016. Pembuatan Prototipe Alat Solar Dryer Berbasis Tenaga Surya Hybrid Sistem Portable. PKMT 3-4-1. 